\title{
SUBJEKTIVNA DOBROBIT: ULOGA EMOCIONALNE KOMPETENTNOSTI I DIMENZIJA PRIVRŽENOSTI
}

\author{
Tatjana Komšo \\ AMEOS Klinikum Bad Aussee \\ Sommersbergeseestraße 395, A-8990 Bad Aussee, Austrija \\ tatjanakomso@gmail.hr \\ Irena Burić \\ Odjel za psihologiju Sveučilišta u Zadru \\ Obala kralja Petra Krešimira IV, br. 2, 23000 Zadar \\ inekic@unizd.hr \\ Marina Vidaković \\ Odjel za psihologiju Sveučilišta u Zadru \\ Obala kralja Petra Krešimira IV, br. 2, 23000 Zadar \\ mjurkin@unizd.hr
}

\begin{abstract}
Sažetak
Istraživanja u području pozitivne psihologije nastoje odgovoriti na pitanja koji su to osobni i okolinski čimbenici koji doprinose sreći i zadovoljstvu u životu pojedinca. U okviru ovog istraživanja cilj je bio ispitati doprinose zasebnih dimenzija emocionalne kompetentnosti (sposobnost uočavanja i razumijevanja emocija, sposobnost izražavanja i imenovanja emocija, sposobnost reguliranja i upravljanja emocijama) i dimenzija privrženosti u različitim bliskim odnosima (partnerski, obiteljski, prijateljski) u objašnjenju subjektivne dobrobiti pojedinca. U istraživanju je sudjelovalo 245 ispitanika u dobi od 18 do 30 godina. Ispitivanje je provedeno putem online upitnika, koji su se temeljili na samoprocjeni ispitanika. Rezultati provedenih hijerarhijskih regresijskih analiza, između ostalog, pokazuju, da emocionalno kompetentniji pojedinci te pojedinci koji su manje skloni izbjegavanju u odnosu s obitelji pokazuju veće zadovoljstvo životom, veći osjećaj prosperiteta te učestaliji doživljaj pozitivnih, a rjeđi doživljaj negativnih iskustava. Uz to, ako je osoba bila muškog spola, mlađa osoba i osoba uspješnija u uočavanju i razumijevanju emocija bez obzira na spol, to je bio manji doživljaj negativnih iskustava.
\end{abstract}

Ključne riječi: subjektivna dobrobit, emocionalna kompetentnost, privrženost 


\section{UVOD}

Subjektivna dobrobit se definira kao pojedinčeva afektivna i kognitivna procjena vlastitog života koja uključuje emocionalne reakcije na različite događaje, ali i kognitivne prosudbe zadovoljstva i ispunjenosti (Diener, Oishi i Lucas, 2009). Svaki pojedinac uz to čini i šire prosudbe o svom životu kao cjelini, ali i o određenim, za pojedinca važnim domenama kao što su primjerice brak i posao. Iz toga slijedi da postoje odvojene komponente subjektivne dobrobiti: zadovoljstvo životom (globalne procjene vlastitog života), zadovoljstvo važnim životnim domenama (npr. zadovoljstvo poslom), pozitivni afekti (iskustvo mnogih ugodnih emocija i raspoloženja) i niske razine negativnih afekata (iskustvo malog broja neugodnih emocija i raspoloženja) (Diener, 2000). Zadovoljstvo životom ključni je indikator subjektivne dobrobiti te predstavlja subjektivnu evaluaciju sveukupne kvalitete života pojedinca (Diener i Diener, 1995). Pregledom literature vidljivo je da se rezultati na mjerama zadovoljstva životom nerijetko koriste kao pokazatelji sreće i dobrog života odnosno depresije i nesreće. Odnosno može se reći da je visoko zadovoljstvo životom povezano sa srećom i 'dobrim životom', dok je nisko zadovoljstvo povezano sa depresijom i nesrećom (Lyubomirsky, King i Diener, 2005).

Postoje različite pretpostavke koje pokušavaju objasniti vezu između emocionalne inteligencije i adaptivnih ishoda, kao što je subjektivna dobrobit. Kao prvo, pod pretpostavkom da su pojedinci s visokom emocionalnom inteligencijom svjesniji svojih emocija i vještiji u njihovoj regulaciji, trebali bi iskusiti manje razine neugode i sa stresom povezanih emocija, što bi zauzvrat pratilo i više razine subjektivne dobrobiti (Salovey, Bedell, Detweiler i Mayer, 1999). Drugo, uzimajući u obzir pretpostavku da pojedinci s višom emocionalnom inteligencijom imaju prednost koja se očituje u višoj socijalnoj kompetenciji, bogatijoj društvenoj mreži i većem broju učinkovitih strategija suočavanja, može se očekivati da bi im sve navedeno moglo služiti u pojačavanju osjećaja subjektivne dobrobiti (Salovey i sur., 1999). Treće, budući da emocije osiguravaju informacije o pojedinčevim odnosima sa okolinom i drugima, interpretacija i odgovor na te informacije može usmjeriti aktivnosti i misli na način da pojačavaju ili održavaju dobrobit (Parrott, 2002). Na kraju, pokazalo se da je emocionalna kompetentnost povezana s manjom sklonošću doživljaja negativnih iskustava i većom sklonošću doživljavanja pozitivnih emocija, te tako pridonosi bogatijem osjećaju subjektivne dobrobiti (Mikolajczak, Nelis, Hansenne i Quoidbach, 2008). Istraživanja čiji je cilj bio utvrditi prediktivnu vrijednost emocionalne kompetentnosti za različite komponente subjektivne dobrobiti, većinom zadovoljstvo životom, ukazuju na to da je emocionalna kompetentnost značajan pozitivan prediktor subjektivne dobrobiti (Bar-On, 2005; Gallagher i Vella-Brodrick, 2008). Istraživanja zaštitne uloge različitih dimenzija emocionalne kompetentnosti za psihološku dobrobit pojedinca ukazuju na važnost tri ključne dimenzije emocionalne kompetentnosti: sposobnost reguliranja i upravljanja emocijama, sposobnost izražavanja i imenovanja emocija te usmjerenost na rješavanje problema (Ciarrochi, Scott, Deane i Heaven, 2003). U prilog ovim nalazima idu i 
rezultati longitudinalne studije (Ciarrochi i Scott, 2006), gdje je utvrđen značajan doprinos navedenih dimenzija emocionalne kompetentnosti u objašnjenju razine anksioznosti, stresa i pozitivnih emocija; odnosno, pojedinci koji imaju razvijenije sposobnosti izražavanja i reguliranja emocijama manje su anksiozni te doživljavaju više pozitivnih emocija. Nadalje, usmjerenost na rješavanje problema izdvaja se kao jedini negativan prediktor stresa, što indicira da pojedini aspekti emocionalne kompetentnosti nisu jednako prediktivni za sve aspekte dobrobiti. Stoga je cilj ovog istraživanja bio utvrditi ulogu specifičnih dimenzija emocionalne kompetentnosti u objašnjenju pojedinih aspekata dobrobiti.

Istraživanja na području socijalne psihologije i psihologije ličnosti o privrženosti kod odraslih upućuju na važnost sigurne privrženosti za psihološko funkcioniranje pojedinca (Mikulincer i Shaver, 2007). U adolescenciji i odrasloj dobi, sigurna privrženost je povezana za zdravim načinom izražavanja emocija, optimističnom procjenom potencijalno prijetećih događaja i efektivnim načinima nošenja sa stresom (Mikulincer i Shaver, 2007). Ovi se nalazi mogu objasniti time što osoba tijekom svog razvoja stvara unutarnje radne modele o sebi i drugima (Bowlby, 1973) koji uključuju i proceduralno znanje o tome kako upravljati neugodnim emocijama, koje se organizira oko relacijskog obrasca sigurne baze (secure-base script). Teoretski, taj obrazac uključuje sljedeću 'ako-onda' propoziciju: "Ako se susretnem sa nekom preprekom $\mathrm{i} / \mathrm{ili}$ iskusim neugodne emocije, mogu se obratiti bliskoj osobi za pomoć. On ili ona će mi vjerojatno biti dostupan/na i pružiti mi podršku. Ja ću stoga osjetiti olakšanje i utjehu kao rezultat bliskosti s tom osobom, te ću se onda moći vratiti drugim aktivnostima." Jednom aktiviran, ovaj skript služi kao vodič u adaptivnom reguliranju kognitivnih i afektivnih procesa i u suočavanju sa stresom i neugodnim situacijama. Prema tome, sigurno privržene osobe imaju pristupačnije, bogatije i više elaborirane skriptove nego nesigurno privržene osobe, bilo anksiozno privržene ili izbjegavajuće privržene, što pridonosi njihovoj emocionalnoj stabilnosti, mentalnom zdravlju, zadovoljavajućim interpersonalnim odnosima i samopouzdanju. Drugim riječima, sigurno privrženi pojedinci su eksperti u korištenju ovih skriptova (Mikulincer i Shaver, 2007).

U prilog tome idu i rezultati istraživanja koji su pokazali da je sigurna privrženost povezana s većom subjektivnom dobrobiti, dok su anksiozni i izbjegavajući stil povezani s nižim razinama subjektivne dobrobiti (Felton i Jowett, 2013). La Guardia i suradnici (2000) su izvijestili da je sigurnija privrženost prema bliskim osobama, roditeljima, romantičnim partnerima, najboljim prijateljima, cimerima i značajnim drugima (učiteljima, poslodavcima), rezultirala većom dobrobiti, koja je mjerena kao kompozitna varijabla, a uključivala je depresiju, vitalnost, anksioznost, fizičke simptome i samopouzdanje. Mehanizam koji bi mogao biti odgovoran za povezanost privrženosti i dobrobiti jesu obrasci procjene stresnih situacija budući da su oni povezani s pojedinčevim vjerovanjima i očekivanjima o tome jesu li sposobni sami se nositi sa stresorima i oduprijeti im se (Karreman i Vingerhoets, 2012). 
Cilj, problemi i hipoteze istraživanja

Cilj, a ujedno i glavni problem ovog istraživanja bio je ispitati doprinose zasebnih dimenzija emocionalne kompetentnosti (sposobnost uočavanja i razumijevanja emocija, sposobnost izražavanja i imenovanja emocija, sposobnost reguliranja i upravljanja emocijama) i dimenzija privrženosti (anksioznost i izbjegavanje) u različitim vrstama bliskih odnosa (partnerski, obiteljski, prijateljski) u objašnjenju subjektivne dobrobiti pojedinca. Pretpostavilo se da će pojedinci koji imaju niži rezultat na obje dimenzije privrženosti (izbjegavanje i anksioznost) te emocionalno kompetentniji pojedinci izvještavati o većoj subjektivnoj dobrobiti, odnosno o većem prosperitetu i zadovoljstvu životom te o više pozitivnih i manje negativnih iskustava.

\section{METODA}

\section{Ispitanici}

$\mathrm{U}$ istraživanju je sudjelovalo 245 ispitanika u dobi od 18 do 30 godina $(\mathrm{M}=$ 23,26, $\mathrm{SD}=3,38$ ). Od toga ih je 32 bilo muškog, a 213 ženskog spola. Po statusu veze ispitanici su bili podijeljeni na samce $(\mathrm{N}=115)$, one koji su u vezi $(\mathrm{N}=105)$ i one koji su u braku $(\mathrm{N}=25)$.

\section{Mjerni instrumenti}

Upitnik emocionalne kompetentnosti (UEK-45; Takšić, 2002) sadrži tri subskale: sposobnost uočavanja i razumijevanja emocija (15 čestica, npr. Kada vidim kako se netko osjeća, obično znam što mu se dogodilo), sposobnost izražavanja i imenovanja emocija (14 čestica, npr. Kada mi nešto ne odgovara, to odmah i pokažem) i sposobnost regulacije i upravljanja emocijama (16 čestica, npr. Kada sam s osobom koja me cijeni, pazim kako se ponašam). U ovom je istraživanju potvrđena faktorska struktura upitnika, te je pouzdanost cijele skale iznosila 0,94 . Pouzdanost pojedinih subskala je iznosila za Uočavanje i razumijevanje emocija 0,92 , za Izražavanje i imenovanje emocija 0,91 i za Regulaciju i upravljanje emocijama 0,79 .

Modificirani Brennanov Inventar iskustava u bliskim vezama (Kamenov i Jelić, 2003). Inventar se sastoji od tri upitnika koji mjere privrženost prema ljubavnim partnerima, članovima obitelji i prijateljima. Svaki upitnik sadrži 18 tvrdnji raspoređenih u dvije podskale: Skalu anksioznosti (9 čestica, npr. Jako se brinem da ću izgubiti prijatelje) i Skalu izbjegavanja (9 čestica, npr. Osjećam se jako neugodno kad sam blizak/bliska s prijateljima). Za Skalu privrženosti prema ljubavnom partneru pouzdanost je iznosila: za subskalu anksioznost 0,82 i za subskalu izbjegavanje 0,90; kod Skale privrženosti članovima obitelji pouzdanost je iznosila: za subskalu anksioznost 0,80 i za subskalu izbjegavanje 0,92; te za Skalu privrženosti 
prema prijateljima, za subskalu anksioznost 0,84 i za subskalu izbjegavanje 0,86 . Analizama su potvrđene faktorske strukture svih triju skala.

Dienerove skale subjektivne dobrobiti: Skala zadovoljstva životom (Satisfaction with Life Scale - SWLS; Diener, Emmons, Larsen i Griffin, 1985), Skala prosperiteta (Flourishing Scale - FS; Diener i sur., 2010) i Skala pozitivnih i negativnih iskustava (Scale of Positive and Negative Experience-SPANE; Diener i sur., 2010) (adaptirane verzije Komšo i Burić, 2016) ${ }^{1}$.

Skala zadovoljstva životom sastoji se od 5 tvrdnji koje se odnose na zadovoljstvo životom. Od sudionika se traži da na skali procjene od 1 do 7 označe u kojoj mjeri se tvrdnje (npr. Moj život je vrlo blizu onome što smatram idealnim) odnose na njihov život. Koeficijent pouzdanosti iznosio je 0,87 .

Skala prosperiteta se sastoji od 8 tvrdnji koje opisuju važne aspekte ljudskog funkcioniranja, od pozitivnih odnosa do osjećaja kompetentnosti i posjedovanja značenja i smisla u životu (npr. Vodim svrhovit i smislen život). Na svaku tvrdnju sudionik daje odgovor na skali procjene od 1 do 7 . Koeficijent pouzdanosti iznosio je 0,89

Skala pozitivnih i negativnih iskustava je kratka skala koja se sastoji od 12 čestica u obliku pridjeva. Šest čestica se odnosi na pozitivna iskustva (npr. Pozitivno, Dobro, Ugodno), a drugih 6 na negativna iskustva (npr. Tužno, Preplašeno, Ljuto). Zadatak ispitanika je da na skali od 1 do 5 procijeni svoja iskustva u posljednja 4 tjedna. Rezultat se formira odvojeno, posebno za negativna i posebno za pozitivna iskustva. Koeficijenti pouzdanosti za Skalu pozitivnih i negativnih iskustava iznose 0,89 i 0,84 .

\section{Postupak}

Istraživanje je provedeno putem online upitnika. Ispitanici su upitnicima mogli pristupiti putem poveznica koje su bile podijeljene na internetskoj društvenoj mreži 'Facebook' i putem portala 'Istražime.com'. Ispitivanje je bilo u potpunosti anonimno, te su se svi podaci bilježili u zajedničkoj tablici na internetskoj stranici $w w w$. docs.google.com, kojoj su pristup imali samo istraživači.

\section{REZULTATI}

Korelacijske i regresijske analize

U Tablici 1 prikazani su bivarijatni koeficijenti korelacije između svih varijabli korištenih u istraživanju te osnovni deskriptivni statistici. U nastavku teksta

1 Faktorska struktura triju skala subjektivne dobrobiti detaljno prikazana u radu Komšo i Burić (2016). 
interpretirane su samo korelacije koje su direktno vezane za problem istraživanja, odnosno korelacije između pojedinih prediktora i kriterija.

Utvrđene su značajne i pozitivne povezanosti između dimenzija emocionalne kompetentnosti i svih aspekata subjektivne dobrobiti, osim kod doživljavanja negativnih iskustava, gdje je povezanost bila značajna i negativna. Emocionalno kompetentniji pojedinci bili su zadovoljniji životom, izvještavali o većem prosperitetu, doživljavali više pozitivnih i manje negativnih iskustava i obrnuto. Anksioznost $\mathrm{i}$ izbjegavanje (dimenzije privrženosti), u sva tri odnosa, u značajnim su i negativnim korelacijama sa zadovoljstvom životom, prosperitetom i pozitivnim iskustvima, dok je suprotan obrazac povezanosti utvrđen s doživljavanjem negativnih iskustava. Pojedinci koji su skloniji izbjegavanju i anksioznosti u obiteljskoj, romantičnoj i prijateljskoj domeni izvještavali su o manjem zadovoljstvu životom, smanjenom osjećaju prosperiteta te o doživljaju manje pozitivnih i više negativnih iskustava.

Da bi se dobio odgovor na postavljeni istraživački problem, to jest da bi se utvrdio doprinos dimenzija emocionalne kompetentnosti i privrženosti u objašnjenju različitih aspekata subjektivne dobrobiti, provedene su hijerarhijske regresijske analize, a rezultati su prikazani u tablicama 2, 3, 4 .

Prvi korak u hijerarhijskim regresijskim analizama bio je uvođenje dimenzija emocionalne kompetentnosti kao prediktora pojedinih aspekata subjektivne dobrobiti. S obzirom na to da je emocionalna kompetentnost $u$ ovom istraživanju određena skupom samoprocijenjenih sposobnosti, pretpostavilo se da je bazičnija u objašnjenju ljudskog ponašanja nego što su to dimenzije privrženosti. U drugom koraku je uvedena privrženost u odnosu s članovima obitelji, nakon toga, u trećem koraku, dimenzije privrženosti u odnosu s prijateljima, te u zadnjem koraku, dimenzije privrženosti u odnosu s ljubavnim partnerima. Logika ovakvog redoslijeda uvođenja prediktora jest ta što se smatra da je obitelj primarni izvor objekata privrženost, dok je vjerojatnije da su ispitanici imali barem jednog bliskog prijatelja nego ljubavnog partnera. Koraci hijerarhijske regresijske analize, kada su kriterij bila negativna iskustva, neznatno su se razlikovali od prije navedenih. Naime, ustanovljena je značajna povezanost između negativnih iskustava i demografskih varijabli, spola i dobi, te su one, u ovom slučaju, uvedene kao prvi korak, dok je redoslijed uvođenja ostalih prediktora ostao nepromijenjen.

Rezultati provedenih hijerarhijskih analiza (Tablica 2) pokazuju da se nakon kontroliranja dimenzija emocionalne kompetentnosti u prvom koraku koje objašnjavaju $26 \%$ varijabiliteta zadovoljstva životom odnosno $39 \%$ varijabiliteta prosperiteta, uvođenjem dimenzija privrženosti, anksioznosti i izbjegavanja u odnosu s članovima obitelji, ukupna objašnjena varijanca zadovoljstva životom značajno povećala, na ukupnih $31 \%$ odnosno prosperiteta na ukupnih $44 \%$. Ispitanici koji su zadovoljniji životom i doživljavaju veći prosperitet, procjenjuju se emocionalno kompetentnijim na dimenzijama sposobnosti izražavanja i imenovanja emocija, sposobnosti regulacije i upravljanja emocijama te u obiteljskim odnosima rjeđe koriste izbjegavanje. Nadalje, uvođenje dimenzije izbjegavanja i anksioznosti u 


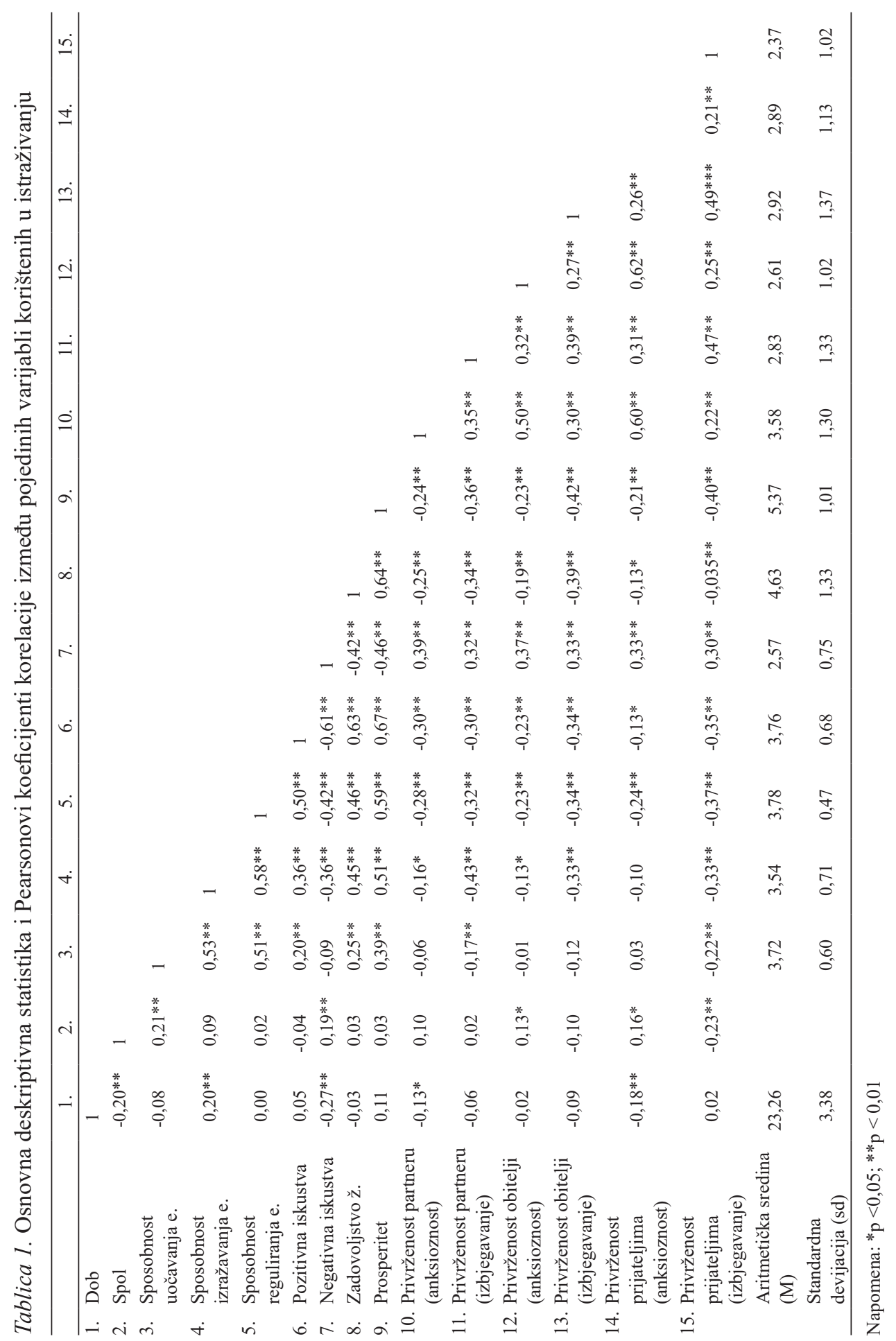


prijateljskim odnosima i odnosima s ljubavnim partnerom, nije značajno doprinijelo povećanju objašnjene varijance zadovoljstva životom i prosperiteta. Dakle, konačna regresijska jednadžba pokazuje da se opisanim setom prediktorskih varijabli može objasniti 33\% ukupne varijance zadovoljstva životom odnosno $45 \%$ varijance prosperiteta. Kao i kod zadovoljstva životom, što su pojedinci imali razvijeniju sposobnost izražavanja i imenovanja emocija, što su bili uspješniji u njihovu reguliranju i upravljanju, a manje skloni izbjegavanju u odnosu s članovima obitelji, to su imali veći osjećaj prosperiteta.

Rezultati provedene hijerarhijske regresijske analize prikazani u Tablici 3 pokazuju da emocionalna kompetentnost objašnjava $27 \%$ ukupne objašnjene varijance

Tablica 2. Rezultati hijerarhijske regresijske analize sa zadovoljstvom životom i prosperitetom kao kriterijima i dimenzijama emocionalne kompetentnosti i privrženosti u različitim vrstama bliskih odnosa kao prediktorskim varijablama

\begin{tabular}{|c|c|c|c|c|c|c|}
\hline \multirow[b]{2}{*}{ Prediktori } & \multicolumn{3}{|c|}{ Zadovoljstvo životom } & \multicolumn{3}{|c|}{ Prosperitet } \\
\hline & Beta & $\Delta R^{2}$ & $R^{2}$ & Beta & $\Delta R^{2}$ & $R^{2}$ \\
\hline \multicolumn{7}{|c|}{ 1. korak: Emocionalna kompetentnost } \\
\hline $\begin{array}{l}\text { Sposobnost uočavanja i } \\
\text { razumijevanja emocija }\end{array}$ & $\begin{array}{c}-0,07 \\
(-0,042)\end{array}$ & & \multirow{3}{*}{0,26} & $\begin{array}{c}0,04 \\
(0,08)\end{array}$ & & \multirow{3}{*}{0,39} \\
\hline $\begin{array}{l}\text { Sposobnost izražavanja i } \\
\text { imenovanja emocija }\end{array}$ & $\begin{array}{l}0,31^{* * *} \\
\left(0,23^{* *}\right)\end{array}$ & & & $\begin{array}{l}0,25 * * * \\
(0,17 *)\end{array}$ & & \\
\hline $\begin{array}{l}\text { Sposobnost reguliranja i } \\
\text { upravljanja emocijama }\end{array}$ & $\begin{array}{l}0,31 * * * \\
(0,23 * *)\end{array}$ & & & $\begin{array}{c}0,43 * * * \\
(0,34 * * *)\end{array}$ & & \\
\hline \multicolumn{7}{|c|}{ 2. korak: Privrženost prema članovima obitelji } \\
\hline Anksioznost & $\begin{array}{l}-0,05 \\
(-0,05)\end{array}$ & \multirow{2}{*}{$0,04 * * *$} & \multirow{2}{*}{$\mathbf{0 , 3 1} * * *$} & $\begin{array}{c}-0,06 \\
(-0,03)\end{array}$ & \multirow{2}{*}{$0,04 * * *$} & \multirow{2}{*}{$0,44 * * *$} \\
\hline Izbjegavanje & $\begin{array}{l}-0,21 * * * \\
(-0,16 *)\end{array}$ & & & $\begin{array}{l}-0,21 * * * \\
(-0,17 * *)\end{array}$ & & \\
\hline \multicolumn{7}{|c|}{ 3. korak: Privrženost prema prijateljima } \\
\hline Anksioznost & $\begin{array}{c}0,07 \\
(0,13)\end{array}$ & \multirow{2}{*}{$\mathbf{0 , 0 1}$} & \multirow{2}{*}{$\mathbf{0 , 3 2}$} & $\begin{array}{l}-0,03 \\
(-0,03)\end{array}$ & \multirow{2}{*}{$\mathbf{0 , 0 1}$} & \multirow{2}{*}{0,45} \\
\hline Izbjegavanje & $\begin{array}{l}-0,10 \\
(-0,09)\end{array}$ & & & $\begin{array}{l}-0,10 \\
(-0,09)\end{array}$ & & \\
\hline \multicolumn{7}{|c|}{ 4. korak: Privrženost prema ljubavnim partnerima } \\
\hline Anksioznost & $\begin{array}{c}-0,12 \\
(-0,12)\end{array}$ & \multirow{2}{*}{$\mathbf{0 , 0 1}$} & \multirow{2}{*}{$\mathbf{0 , 3 3}$} & $\begin{array}{c}0,00 \\
(0,00)\end{array}$ & \multirow{2}{*}{$\mathbf{0 , 0 0}$} & \multirow{2}{*}{0,45} \\
\hline Izbjegavanje & $\begin{array}{l}-0,05 \\
(-0,05)\end{array}$ & & & $\begin{array}{c}-0,04 \\
(-0,04)\end{array}$ & & \\
\hline
\end{tabular}

Napomena: ( ) - rezultati iz zadnjeg koraka hijerarhijske regresijske analize, ${ }^{*} p<0,05,{ }^{* *} p<0,01$, $* * * p<0,001$ 
Tablica 3. Prikaz rezultata hijerarhijske regresijske analize s pozitivnim iskustvima kao kriterijem i dimenzijama emocionalne kompetentnosti i privrženosti u različitim vrstama bliskih odnosa kao prediktorskim varijablama

\begin{tabular}{|c|c|c|c|}
\hline \multirow[b]{2}{*}{ Prediktori } & \multicolumn{3}{|c|}{ Pozitivna iskustva } \\
\hline & Beta & $\Delta R^{2}$ & $R^{2}$ \\
\hline \multicolumn{4}{|l|}{ 1. korak: Emocionalna kompetentnost } \\
\hline Sposobnost uočavanja i razumijevanja emocija & $\begin{array}{c}-0,13 \\
(-0,11)\end{array}$ & & \multirow{3}{*}{$\mathbf{0 , 2 7}$} \\
\hline Sposobnost izražavanja i imenovanja emocija & $\begin{array}{l}\mathbf{0 , 1 5 *} \\
(0,08)\end{array}$ & & \\
\hline Sposobnost reguliranja i upravljanja emocijama & $\begin{array}{c}0,48 * * * \\
(0,41 * * *)\end{array}$ & & \\
\hline \multicolumn{4}{|l|}{ 2. korak: Privrženost prema članovima obitelji } \\
\hline Anksioznost & $\begin{array}{c}-0,08 \\
(-0,09)\end{array}$ & \multirow{2}{*}{$\mathbf{0 , 0 3 * *}$} & \multirow{2}{*}{$\mathbf{0 , 3 0}$ ** } \\
\hline Izbjegavanje & $\begin{array}{l}-\mathbf{0 , 1 5 *} \\
(-0,09)\end{array}$ & & \\
\hline \multicolumn{4}{|l|}{ 3. korak: Privrženost prema prijateljima } \\
\hline Anksioznost & $\begin{array}{c}0,12 \\
(\mathbf{0 , 2 1} * *)\end{array}$ & \multirow{2}{*}{$0,02 *$} & \multirow{2}{*}{$0,32 *$} \\
\hline Izbjegavanje & $\begin{array}{l}-0,12 \\
(-0,11)\end{array}$ & & \\
\hline \multicolumn{4}{|l|}{ 4. korak: Privrženost prema ljubavnim partnerima } \\
\hline Anksioznost & $\begin{array}{c}-0,19 * * \\
(-0,19 * *)\end{array}$ & \multirow{2}{*}{$0,02 *$} & \multirow{2}{*}{$0,34 *$} \\
\hline Izbjegavanje & $\begin{array}{c}-0,03 \\
(-0,03)\end{array}$ & & \\
\hline
\end{tabular}

Napomena: ( ) - rezultati iz zadnjeg koraka hijerarhijske regresijske analize, ${ }^{*} p<0,05,{ }^{* *} p<0,01$, $* * * p<0,001$

doživljenih pozitivnih iskustava. Ispitanici koji su bili sposobniji u izražavanju i imenovanju emocija i u regulaciji i upravljanju istih, doživljavaju više pozitivnih iskustava. Uvođenjem prediktorske varijable privrženost prema članovima obitelji u drugom koraku, ukupna objašnjena varijanca pozitivnih iskustava značajno se povećava na 30\%. Ispitanici kod kojih je u odnosu s članovima obitelji izbjegavajuća privrženost bila manje izražena imali su više pozitivnih iskustava. Dodavanje prediktora privrženost prema prijateljima u trećem koraku, objašnjenu varijancu pozitivnih iskustava značajno povećava za $2 \%$. Beta ponderi u ovom koraku nisu značajni, ni za dimenziju anksioznosti ni za dimenziju izbjegavanja. Uvođenjem privrženosti prema ljubavnom partneru u regresijsku jednadžbu, beta ponder za 
dimenziju anksioznosti u prethodnom koraku postaje značajan. Ispitanici koji su u prijateljskim odnosima bili više anksiozno privrženi, doživljavali su više pozitivnih iskustava. U četvrtom koraku ukupna se objašnjena varijanca pozitivnih iskustava značajno povećava te sada iznosi $34 \%$, s tim da je manja anksioznost u odnosu s ljubavnim partnerom pridonosila doživljaju više pozitivnih iskustava. U završnom

Tablica 4. Prikaz rezultata hijerarhijske regresijske analize s negativnim iskustvima kao kriterijem i dimenzijama emocionalne kompetentnosti i privrženosti u različitim vrstama bliskih odnosa kao prediktorskim varijablama

\begin{tabular}{|c|c|c|c|}
\hline \multirow[b]{2}{*}{ Prediktori } & \multicolumn{3}{|c|}{ Negativna iskustva } \\
\hline & Beta & $\Delta R^{2}$ & $R^{2}$ \\
\hline \multicolumn{4}{|l|}{ 1. korak } \\
\hline Dob & $\begin{array}{l}-0,24 * * * \\
(-0,18 * *)\end{array}$ & & \multirow{2}{*}{0,09} \\
\hline Spol & $\begin{array}{c}0,15^{*} \\
\left(0,15^{* *}\right)\end{array}$ & & \\
\hline \multicolumn{4}{|l|}{ 2. korak: Emocionalna kompetentnost } \\
\hline Sposobnost uočavanja i razumijevanja emocija & $\begin{array}{l}\mathbf{0 , 1 8 *} \\
(0,12)\end{array}$ & \multirow{3}{*}{$0,21 * * *$} & \multirow{3}{*}{$0,30 * * *$} \\
\hline Sposobnost izražavanja i imenovanja emocija & $\begin{array}{c}-\mathbf{0 , 2 0} * * \\
(-0,14)\end{array}$ & & \\
\hline Sposobnost reguliranja i upravljanja emocijama & $\begin{array}{c}-0,40 * * * \\
(-0,26 * * *)\end{array}$ & & \\
\hline \multicolumn{4}{|l|}{ 3. korak: Privrženost prema članovima obitelji } \\
\hline Anksioznost & $\begin{array}{c}0,23 * * * \\
(0,17 *)\end{array}$ & \multirow{2}{*}{$0,07 * * *$} & \multirow{2}{*}{$0,37 * * *$} \\
\hline Izbjegavanje & $\begin{array}{l}\mathbf{0 , 1 3 *} \\
(0,07)\end{array}$ & & \\
\hline \multicolumn{4}{|l|}{ 4. korak: Privrženost prema prijateljima } \\
\hline Anksioznost & $\begin{array}{c}0,01^{*} \\
(-0,06)\end{array}$ & \multirow{2}{*}{0,01} & \multirow{2}{*}{$\mathbf{0 , 3 8}$} \\
\hline Izbjegavanje & $\begin{array}{c}0,12 \\
(0,11)\end{array}$ & & \\
\hline \multicolumn{4}{|l|}{ 5. korak: Privrženost prema ljubavnim partnerima } \\
\hline Anksioznost & $\begin{array}{c}0,16^{*} \\
\left(0,16^{*}\right)\end{array}$ & \multirow{2}{*}{$\mathbf{0 , 0 1}$} & \multirow{2}{*}{$\mathbf{0 , 3 9}$} \\
\hline Izbjegavanje & $\begin{array}{c}0,01 \\
(0,01)\end{array}$ & & \\
\hline
\end{tabular}

Napomena: ( ) - rezultati iz zadnjeg koraka hijerarhijske regresijske analize, ${ }^{*} p<0,05,{ }^{* *} p<0,01$, $* * * p<0,001$ 
koraku hijerarhijske regresijske jednadžbe ukupni postotak objašnjene varijance pozitivnih iskustava iznosio je 34\%. Ispitanici koji su uspješnije regulirali i upravljali svojim emocijama te bili manje anksiozni u odnosu s partnerom, a izražavali veći stupanj anksioznosti u odnosima s prijateljima doživljavali su više pozitivnih iskustava.

Rezultati prikazani u Tablici 4 pokazuju da se nakon kontroliranja sociodemografskih varijabli (dob i spol) u prvom koraku, koje objašnjavaju 9\% varijance negativnih iskustava, uvođenjem dimenzija emocionalne kompetentnosti u drugom koraku ukupna objašnjena varijanca negativnih iskustava značajno se povećava na $30 \%$. Manje negativnih iskustava su doživljavali mlađi ispitanici, muškarci, pojedinci koji su imali razvijenije sposobnosti izražavanja i imenovanja te regulacije i upravljanja emocija, kao i oni pojedinci koji postižu manje rezultate za sposobnost uočavanja i razumijevanja emocija. Uvođenjem mjera privrženosti prema članovima obitelji, u trećem koraku, postotak objašnjene varijance značajno se povećava, te iznosi $37 \%$. Više negativnih iskustava doživljavali su pojedinci kod kojih je bila izraženija anksiozna i izbjegavajuća privrženost u odnosu s članovima obitelji. Međutim, više negativnih iskustava doživljavali su pojedinci koji su imali izraženiju anksioznu privrženost $u$ odnosu sa svojim ljubavnim partnerom. U krajnjoj regresijskoj jednadžbi, setom prediktorskih varijabli objašnjeno je 39\% ukupne varijance negativnih iskustava. O manje negativnih iskustava izvještavali su pojedinci koji su bili mlađi, muškog spola, ispitanici koji su imali izraženiju sposobnost reguliranja i upravljanja emocijama te oni kod kojih je anksioznost s ljubavnim partnerom i članovima obitelji bila manje izražena.

\section{RASPRAVA}

U zadnjih nekoliko desetljeća sve se više pažnje pridaje istraživanju područja pozitivne psihologije. Istraživače zanima koje varijable mogu doprinijeti čovjekovoj sreći i koje su to karakteristike koje posjeduje sretna i zadovoljna osoba. Jedan od najvažnijih konstrukata u spomenutoj domeni istraživanja jest subjektivna dobrobit, stoga je cilj ovog istraživanja bio ispitati doprinose zasebnih dimenzija emocionalne kompetencije i dimenzija privrženosti u različitim bliskim odnosima (partnerski, obiteljski, prijateljski) u objašnjenju subjektivne dobrobiti pojedinca.

Rezultati provedenih hijerarhijskih regresijskih analiza pokazuju da su sposobnost izražavanja i imenovanja emocija, te sposobnost reguliranja i upravljanja emocijama značajni prediktori za sve mjerene aspekte subjektivne dobrobiti. Navedene sposobnosti imaju značajan doprinos u objašnjavanju zadovoljstva životom, prosperiteta te pozitivnih i negativnih iskustava. Drugim riječima, pojedinci koji su bili uspješniji u izražavanju, imenovanju, regulaciji i upravljanju svojim osjećajima izvještavali su o većem zadovoljstvu životom, višim razinama prosperiteta te su imali više pozitivnih i manje negativnih iskustava. Nekoliko je načina na koji se dobiveni 
rezultati mogu objasniti. Naime, pojedinci s visokom emocionalnom kompetentnosti svjesniji su svojih emocija i vještiji u njihovoj regulaciji, te će zbog toga iskusiti manje razine neugode i sa stresom povezanih emocija, što zauzvrat doprinosi višim razinama subjektivne dobrobiti (Salovey i sur., 1999). Moguće je da su pojedinci s razvijenijim emocionalnim kompetencijama vjerojatno i društveno kompetentniji, imaju bogatiju društvenu mrežu i više učinkovitih strategija suočavanja, te zbog toga imaju pojačan osjećaj subjektivne dobrobiti (Salovey i sur., 1999). Pokazalo se da je emocionalna kompetentnost povezana s nižom sklonošću doživljavanju negativnih iskustava i većom sklonošću doživljavanja pozitivnih emocija te je moguće da tako pridonosi bogatijem osjećaju subjektivne dobrobiti (Mikolajczak i sur., 2008), što je dobiveno i u ovom istraživanju.

Značajan i konzistentan prediktor svih aspekata subjektivne dobrobiti, kada je riječ o privrženosti, bila je izbjegavajuća privrženost u odnosu s članovima obitelji; odnosno, izraženije izbjegavanje je u navedenim odnosima konzistentno doprinosilo manjem zadovoljstvu životom, smanjenom osjećaju prosperiteta, manjem broju pozitivnih i većem broju negativnih iskustava. S obzirom na to da je obitelj primarni izvor bliskih odnosa, ovi rezultati i nisu toliko iznenađujući. Izbjegavajući odnos sa članovima obitelji uvelike može utjecati na različite sfere svakodnevnog funkcioniranja pojedinca. Izbjegavanje bliskosti je usko povezano s modelom o drugima, a odnosi se na doživljaj neugode zbog bliskosti i ovisnosti o drugima (Kamenov i Jelić, 2003). S obzirom na to da je ispitani uzorak bio u dobi od 18 do 30 godina te se sastojao od oko $3 / 5$ studenata i oko 30 nezaposlenih, može se pretpostaviti da je veliki broj ispitanika bio u većoj ili manjoj mjeri još uvijek ovisan o pomoći svojih roditelja ili drugih članova obitelji radi troškova studiranja ili financijske pomoći nakon studija, prije pronalaska posla. Osjećaj ovisnosti zbog financija ili zbog nekih drugih faktora, koji se pojavljuje kod ove dobne skupine, kod pojedinaca s izraženijom izbjegavajućom privrženosti stoga može nepovoljno djelovati na različite aspekte subjektivne dobrobiti.

Kod doživljavanja pozitivnih iskustava, značajan prediktor je bila i dimenzija anksioznosti kod partnerskih i prijateljskih odnosa. Međutim, zanimljivo je primijetiti da je izraženija anksioznost u prijateljskim odnosima doprinosila češćem doživljavanju pozitivnih iskustava, dok ih je u odnosu s ljubavnim partnerom umanjivala. Anksioznu privrženost karakterizira strah od napuštanja i potreba za ekstremnom bliskošću. S obzirom na to da se prijateljski i partnerski odnosi razlikuju po intenzitetu, bliskosti i intimnosti, moglo bi se pretpostaviti da anksioznost u odnosu s ljubavnim partnerom dolazi više do izražaja. Naime, kod anksiozno privrženih pojedinaca se, kad se susretnu sa stresnim situacijama i kad se pojavi strah od napuštanja ili sumnja u partnerovu ljubav, pojavljuje hiperaktivacija sustava privrženosti (Mikulincer i Florian, 2003). Ovi pojedinci tada pokušavaju minimalizirati distancu prema objektima privrženosti i maksimalizirati sigurnost u tom odnosu (Mikulincer i Florian, 2003). Ovom strategijom anksiozni pojedinci pokušavaju izazvati pozitivne afekte i reakcije kod svojih partnera, te postaju 'ljepljivi', kontrolirajući i 
prepažljivi. Problem kod ove strategije jest to što može izazvati preveliku anksioznu usredotočenost na negativne emocije povezane s privrženošću te tako dovesti do prevelike okupacije odnosom, anksioznih zahtjeva za bliskošću, konfliktnih emocija prema drugima, straha od odbijanja i nesposobnosti napuštanja frustrirajućih partnera (Brennan i Shaver, 1995; Hazan i Shaver, 1987). Hiperaktivacija anksioznog stila privrženosti stoga može dovesti do toga da se velik dio pažnje usmjeri na neugodne emocije, te da pojedinci ruminiraju o njihovim uzrocima i značenju i ustraju na sličnim negativnim mislima, sjećanjima i emocijama (Karreman i Vingerhoets, 2012). Kao rezultat toga, anksiozno privržene osobe imaju slobodan pristup negativnim emocijama i mislima i nisu u mogućnosti ili ne žele svladati ta negativna unutarnja iskustva, pa mogu postati preopterećeni negativnim osjećajima prema sebi i svijetu (Mikulincer, 1998). Zbog svega navedenog, izraženija anksiozna privrženost može objasniti dobivene rezultate, odnosno rjeđe doživljavanje pozitivnih, a češće doživljavanje negativnih iskustava u odnosu s ljubavnim partnerom. Anksiozna privrženosti u prijateljskim odnosima nema tako negativan utjecaj na doživljavanje pozitivnih iskustava; naprotiv, pridonosi im jer se u ovom tipu odnosa možda drugačije očituje. Zbog potrebe za bliskošću i straha od napuštanja pojedinci nastoje održavati odnose sa svojim prijateljima, pa je moguće da ulažu više napora kako bi to ostvarili. Moglo bi se pretpostaviti da zato češće organiziraju zajednička druženja, koja su sama po sebi najvjerojatnije zabavna, te se općenito više trude kod prijatelja izazvati pozitivne reakcije, što zauzvrat može rezultirati pozitivnim ishodima. Stoga se anksioznost u ovakvoj vrsti odnosa pokazala prediktorom pozitivnih iskustava. S obzirom na to da prijateljski odnosi ne moraju nužno biti toliko intimni kao romantični, moguće je da negativne karakteristike ove dimenzije privrženosti ne dolaze toliko do izražaja kao što to može biti slučaj u odnosu s partnerom, kada se može očitovati u ljubomori, pretjeranoj kontroli i nepovjerenju prema partneru (Collins i Read, 1990). No ipak, budući da je ovaj nalaz o pozitivnom doprinosu dimenzije anksioznosti doživljavanju pozitivnih iskustava u prijateljskim odnosima neočekivan, nužne su daljnje provjere dobivenih nalaza prvenstveno zbog dobne $\mathrm{i}$ spolne specifičnosti uzorka.

Demografske varijable bile su značajni prediktori jedino kod doživljavanja negativnih iskustava. Naime, manje negativnih iskustava su doživljavali muškarci i mlađi ispitanici. Prijašnje studije pokazuju da žene češće izvještavaju o negativnim afektima nego muškarci, pogotovo o tuzi i anksioznosti (Thomsen, Mehlsen, Viidik, Sommerlund, Zachariae, 2005). Uz to, prevalencija depresije i većine anksioznih poremećaja je oko dva puta češća kod žena nego kod muškaraca (Nolen-Hoeksema i Aldao, 2011). U ovom istraživanju suprotno nalazima prethodnih istraživanja dobiveno je da stariji ispitanici doživljavaju više negativnih iskustava. Dobiveni rezultati mogli bi se objasniti životnim događajima koji su vezani za mlađu odraslu dob. Naime, u životu mladih, u tome razdoblju dolazi do velikih životnih promjena, od napuštanja roditeljskog doma, početka studiranja, završavanja studija, traženja posla, zapošljavanja i slično. Sve spomenuto može biti stresno za mladu osobu i 
na taj način povećati subjektivni doživljaj negativnih iskustava. Uz to, tranziciju iz sustava obrazovanja u poslovni svijet mogu pratiti i druge promjene, uključujući stupanje u ozbiljnije veze, osnivanje obitelji i promjene u socijalnom okruženju (Wrzus, Haenel, Wagner i Neyer, 2013). Navedene promjene mogu biti jako izazovne te utjecati na razlike $\mathrm{u}$ razinama subjektivne dobrobiti, kao što je dobiveno $\mathrm{i}$ u ovom istraživanju.

Nalazi ovog istraživanja pokazuju da su se dimenzije emocionalne kompetentnosti pokazale prediktivnijima za objašnjenje subjektivne dobrobiti pojedinca nego pojedine dimenzije privrženosti te pružaju potencijalno važne implikacije za buduća istraživanja i praktičnu primjenu bilo u edukacijske, kliničke ili neke druge svrhe. Naime, poznato je da se različitim intervencijama može utjecati na razvijanje emocionalne kompetentnosti, a samim time moglo bi se doprinijeti i subjektivnoj dobrobiti pojedinca.

Važno je spomenuti da je istraživanje imalo i svoje nedostatke. Prvo treba naglasiti da je ovo bilo korelacijsko istraživanje, te da je na temelju rezultata nemoguće izvući zaključke o uzročno-posljedičnoj vezi između ispitanih konstrukata. Uzimajući to u obzir, redoslijed uvođenja pojedinih prediktora u regresijske analize mogao je biti i drugačiji, odnosno dimenzije privrženosti mogle su imati prednost u odnosu na dimenzije emocionalne kompetentnosti prvenstveno uzimajući u obzir etološko-evolucijsku perspektivu u sklopu teorije privrženosti. Nadalje, mjere koje su korištene za ispitivanje pojedinih konstrukata oslanjaju se na metodu samoprocjene, dakle postoji mogućnost davanja socijalno poželjnih odgovora. Još jedan nedostatak istraživanja je i selekcioniranost uzorka. Naime, samim time što je ispitivanje provedeno putem interneta, preko društvene mreže Facebook ili internetske stranice Istražime.com, oni pojedinci koji nemaju pristup internetu, svoj Facebook profil ili nisu upoznati sa stranicom Istražime.com, nisu mogli sudjelovati u istraživanju. Još jedan faktor koji može utjecati na rezultate online istraživanja jest privatnost na internetu; ako ispitanik smatra da je narušena, moguće je da će se to očitovati i u dobivenim rezultatima. Potrebno je naglasiti i to da je uzorak bio spolno pristran, drugim riječima, u istraživanju je od ukupno 245 ispitanika, njih samo 32 bilo muškog spola. S obzirom na dobnu strukturu uzorka (18-30 godina), dobivene rezultate je potrebno verificirati na drugim uzorcima.

\section{ZAKLJUČAK}

U objašnjenju zadovoljstva životom, prosperiteta i doživljavanja pozitivnih iskustava prediktivnima su se pokazale sposobnosti izražavanja, imenovanja, reguliranja i upravljanja emocijama, a za objašnjenje doživljavanja negativnih iskustava, uz već navedene sposobnosti, bilo je prediktivno i uočavanje i razumijevanje emocija te spol i dob osobe. Izbjegavajuća privrženost prema članovima obitelji pokazala se važnim za objašnjenje svih aspekata subjektivne dobrobiti, dok je ank- 
siozna privrženost prema ljubavnim partnerima i prijateljima bila prediktor $u$ objašnjenju doživljavanja pozitivnih i negativnih iskustava.

\section{LITERATURA}

Bar-On, R. (2005). The impact of emotional intelligence on subjective well-being. Perspectives in Education, 23, 41-61.

Bowlby, J. (1973). Attachment and loss: Separation, anxiety, and anger. New York: Basic Books.

Brennan, K.A. i Shaver, P.R. (1995). Dimensions of adult attachment, affect regulation, and romantic relationship functioning. Personality and Social Psychology Bulletin, 21, 267-283.

Ciarrochi, J. i Scott, G. (2006). The link between emotional competence and well-being: a longitudinal study. British Journal of Guidance and Counselling, 34, 231-243.

Ciarrochi, J., Scott, G., Deane, F.P. i Heaven, P.C.L. (2003). Relations between social and emotional competence and mental health: a construct validation study. Personality and Individual Differences, 35, 1947-1963.

Collins, N.L. i Read, S.J. (1990). Adult Attachment, Working Models, and Relationship Quality in Dating Couples. Journal of Personality and Social Psychology, 58, 644-663.

Diener, E. (2000). Subjective well-being: The science of happiness and a proposal for national index. American Psychologist, 55, 34-43.

Diener, E. i Diener, M. (1995). Cross-cultural correlates of life satisfaction and self-esteem. Journal of Personality and Social Psychology, 68, 653-663.

Diener, E., Emmons, R.A., Larsen, R.J. i Griffin, S. (1985). The Satisfaction with Life Scale. Journal of Personality Assessment, 49, 71-75.

Diener, E., Oishi, S. i Lucas, R.E. (2009). Subjective well-being: The science of happiness and life satisfaction. U: S.J. Lope i C.R. Snyder (ur.), (str. 187-194). New York: Oxford University Press.

Diener, E., Wirtz, D., Tov, W., Kim-Prieto, C., Choi, D., Oishi, S. i Biswass-Diener, R. (2010). New Well-being Measures: Short Scales to Assess Flourishing and Positive and Negative Feeling. Social Indicators Research, 97, 143-156.

Felton, L. i Jowett, S. (2013). Attachment and well-being: The mediating effects of psychological needs satisfaction within the coach-athlete and parent-athlete relational contexts. Psychology of Sport and Exercise, 14, 57-65.

Gallagher, E.N. i Vella-Brodrick, D.A. (2008). Social support and emotional intelligence as predictors of subjective well-being. Personality and Individual Differences, 44, 15511561.

Hazan, C. i Shaver, P. R. (1987). Romantic love conceptualized as an attachment process. Journal of Personality and Social Psychology, 52, 511-524.

Kamenov, Ž. i Jelić, M. (2003). Validacija instrumenta za mjerenje privrženosti u različitim vrstama bliskih odnosa: Modifikacija Brennanova Inventara iskustava u bliskim vezama. Suvremena psihologija 6(1), 73-91. 
Karreman, A. i Vingerhoets, A.J.J.M. (2012). Attachment and well-being: The mediating role of emotion regulation and resilience. Personality and Individual Differences, 53, 821-826.

Komšo, T. i Burić, I. (2016). Dienerove skale subjektivne dobrobiti: Skala zadovoljstva životom, Skala prosperiteta i Skala pozitivnih i negativnih iskustava. U: Tucak Junaković, I., Burić, I., Ćubela Adorić, V., Proroković, A., Slišković, A. (Ur). Zbirka psihologijskih skala i upitnika VIII. Sveučilište u Zadru, str.7-17.

La Guardia, J. G., Ryan, R. M., Couchman, C. E. i Deci, E. L. (2000). Within-person variation in security of attachment: A self-determination theory perspective on attachment, need fulfillment, and well-being. Journal of Personality and Social Psychology, 79, 367-384.

Lyubomirsky, S., King, L. i Diener, E. (2005). The benefits of frequent positive affect: Does happiness lead to success? Psychological Bulletin, 131, 803-855.

Mikolajczak, M., Nelis, D., Hansenne, M. i Quoidbach, J. (2008). If you can regulate sadness, you can probably regulate shame: Associations between trait emotional intelligence, emotion regulation and coping efficiency across discrete emotions. Personality and Individual Differences, 44, 1356-1368.

Mikulincer, M. (1998). Adult attachment style and affect regulation: Strategic variations in self-appraisals. Journal of Personality and Social Psychology, 75, 420-435.

Mikulincer, M. i Florian, V. (2003). Attachment Style and Affect Regulation: Implications for Coping with Stress and Mental Health. U G.J.O. Fletcher i M.S. Clark (ur.), Blachwell Handbook of Social Psychology: Interpersonal Processes (str. 537-557). Oxford, UK: Blackwell Publishers.

Mikulincer, M. i Shaver, P. R. (2007). Boosting attachment security to promote mental health, prosocial values, and ineter-group tolerance. Psychological Inquiry, 18, 139-156.

Mikulincer, M., Shaver, P.R., Sapir-Lavid, Y. i Avihou-Kanza, N. (2009). What's inside the mind of Securely and Insecurely Attached People? The Secure-Base Script and Its Associations with Attachment-Style Dimensions. Journal of Personality and Social Psychology, 97, 615-633.

Nolen-Hoeksema, S. i Aldao, A. (2011). Gender and age differences in emotion regulation strategies and their relationship to depressive symptoms. Personality and Individual Differences, 51, 704-708.

Parrott W.G. (2002). The functional utility of negative emotions. In L. Feldman Barrett and P. Salovey (Eds.), The Wisdom in Feeling: Psychological Processes in Emotional Intelligence, ed. (pp. 341-359). New York: Guilford.

Salovey, P., Bedell, B.T., Detweiler, J.B. i Mayer, J.D. (1999). Coping intelligently: Emotional intelligence and coping process. U: C. R. Snyder (ur.), (str. 141-165). Coping: The psychology of what works. New York: Oxford University Press.

Takšić, V. (2002). The importance of emotional intelligence (competence) in positive psychology. First International Positive Psychology Summit, Washington, DC, 4-6.

Thomsen, D.K., Mehlsen, M.Y., Viidik, A., Sommerlund, B. i Zachariae, R. (2005). Age and gender differences in negative affect- Is there a role for emotion regulation? Personality and Individual Differences, 38, 1935-1946.

Wrzus, C., Haenel, M., Wagner, J. i Neyer, F. J. (2013). Social network changes and life events across the life span: a meta-analysis. Psychological Bulletin, 139, 53-80. 


\title{
SUBJECTIVE WELL-BEING: THE ROLE OF EMOTIONAL COMPETENCE AND ATTACHMENT
}

\begin{abstract}
The research in the field of positive psychology is focused on personal and environmental factors that contribute to happiness and life satisfaction. The aim of this study was to examine the contribution of different dimensions of emotional competence (ability to observe and understand emotions, ability to express and name emotions, ability to regulate and manage emotions) and attachment dimensions in different kinds of close relationships (with romantic partners, family members and friends) in the explanation of subjective well-being. The study was conducted on 245 adults, aged 18 to 30 . An online, self-report based questionnaire was used. Results of hierarchical regression analyses showed that greater life satisfaction and flourishing, more positive and less negative experiences were found in individuals with a greater ability of expressing, naming, regulating and managing emotions, and those individuals who were less avoidant in the relationship with their family members. Also, the younger, especially male subjects, and subjects who were more successful in perceiving and understanding emotions, were less likely to encounter negative experiences.
\end{abstract}

Keywords: subjective well-being, emotional competence, attachment

Primljeno: 21. 06. 2018. 
